\section{Demokratický deficit v islámských zemích}

\section{Democratic Deficit in Islamic Countries}

Acta Fakulty filozofické Západočeské univerzity v Plzni /

West Bohemian Review of Social Sciences \& Humanities 2021, OnlineFirst DOl: https://doi.org/10.24132/actaff.2021.13.1.1 https://actaff.zcu.cz/ ISSN 2336-6346

\author{
Pavla Vítová* (iD , Jaromír Harmáček \\ Palacký University Olomouc, Czech Republic
}

\begin{abstract}
United Nations Development Programme (UNDP) identified in 2002 three fundamental areas of human development in which the Arab world lags behind the rest of the world. One of those specified areas was the lack of freedom and democracy. To investigate the presence of the democratic deficit, the study introduces a composite democracy index that measures and compares countries' performances in the democratic domains. This paper aims to define and describe the democratic deficit in the context of the Islamic world, verify its existence in the Arab world, and determine its possible presence in other Muslim countries in various world regions. The study results showed that although the deficit was formulated almost twenty years ago, it is still relevant. It has been observed that Muslim countries performed, on average, worse on the index score than non-Muslim countries, which means that the Islamic countries face the democratic deficit. Moreover, the results showed that the performance of the Arab world in the democratic index is even worse than that of the other Muslim countries. The analysis additionally confirmed that the economic factor is important in verification of the deficit and its depth. On the level of individual countries, poor Muslim states often achieved the worst results, usually from the group of the least developed countries, such as Yemen, Somalia, Sudan, or Eritrea.
\end{abstract}

\title{
Keywords
}

democracy, democratic deficit, Arab world, Muslim countries, democratic index, Arab Human Development Report 4.0 International License.

\section{Úvod}

Demokratická forma vlády, jež lpí na svobodách a lidských právech jako základních hodnotách, představuje alternativu $\mathrm{k}$ despotickým režimům (Kirkpatrick 1984). Vyznačuje se konáním pravidelných voleb, zaváděním většinového pravidla při současné ochraně menšin, ústavní vládou, pluralitním systémem politických stran, oddělením a vzájemným vyvažováním jednotlivých složek moci, svobodnými médii či tržní ekonomikou (Dufek et al. 2019). Také filozofové a myslitelé současného Arabského světa se kloní k názoru, že svoboda, kromě dalších rysů státních zřízení,

\footnotetext{
* Corresponding Author: Pavla Vítová, Katedra rozvojových a environmentálních studií, Př́rodovědecká fakulta Univerzity Palackého v Olomouci, 17. listopadu 12, 77146 Olomouc. E-mail: pavla.vitova@upol.cz.
} 
představuje nezbytnou podmínku pro novou arabskou renesanci (Hassouna 2001). Zajištěním základních lidských práv a svobod a ukončením autokratických despotických vlád mohou státy regionu čelit vnitřním a vnějším výzvám, jako je např. vysoká nezaměstnanost nebo slabě rozvinutý privátní sektor (Hellyer 2018). Percepce svobody může být chápána dvěma způsoby: (a) úzkou definicí omezující svobodu na politická a občanská práva, (b) komplexní definicí zahrnující kromě zmíněných politických a občanských práv také svobodu od útlaku, osvobození člověka od všech faktorů potlačujících lidskou důstojnost, jakými jsou např́íklad hlad, nemoci, chudoba, strach či negramotnost (AHDR 2004).

Svoboda lidí musí být zaručena, udržována a podporována společenskými strukturami a procesy. Řádná správa věcí veřejných ve svobodném státě zaručuje rozšiřování svobod lidí prostřednictvím účasti veřejnosti na fungování státu (Kirkpatrick 1984). Ve svobodném státě existují moderní instituce, které pracují efektivně a transparentně ve prospěch obyvatel, jejichž zástupci jsou pravidelně voleni. Právo v takovém státě je spravedlivé, chrání svobodu, je nadřazené všem a všemu a platí pro všechny. Nezávislý soudní systém podporuje dodržování zákona a exekutivní moc řádně implementuje soudní rozhodnutí. Jedinec je svobodný pouze ve svobodném demokratickém státě a v rámci svobodného národa (AHDR 2004).

$\mathrm{V}$ roce 2002 byly pro centrum islámského světa, tedy Arabský svět, ${ }^{1}$ stanoveny organizací $\mathrm{UNDP}^{2}$ v první zprávě o arabském lidském rozvoji ${ }^{3}$ tři fundamentální oblasti, ve kterých region v porovnání se zbytkem světa zaostává. Jednou ze stanovených oblastí je (kromě vzdělání a rovnosti mužů a žen) také demokracie a svobody (AHDR 2002). Svobody v Arabském světě jsou ohroženy dvěma hlavními vlivy: (1) nedemokratickými režimy a (2) tradičním kmenovým uspořádáním společnosti, které se $\mathrm{v}$ některých případech zaměňuje za náboženství (Freedom House 2018). Zpráva AHDR vznikla pro potřeby zemí Arabského světa, avšak je-li Arabský svět považován za centrum islámského světa, je možné usuzovat, že muslimský svět jako celek čelí obdobnému demokratickému deficitu? Zpráva navíc vznikla již v roce 2004, tedy před událostmi tzv. Arabského jara. Posílily tyto události demokracii ve studovaném regionu, resp. muslimských zemích, nebo lze deficit považovat stále za aktuální?

Tato studie se pokouší kvantifikovat demokratický deficit, a to pomocí konstrukce složeného indexu, který měří výkon jednotlivých zemí světa v oblasti demokracie. ${ }^{4}$ Deficit je pak definován jako rozdíl průměrných hodnot indexu mezi srovnávanými skupinami zemí. Jedním z cílů studie je ověřit existenci deficitu v Arabském světě, pro který byl deficit původně identifikován. Zejména se však článek zaměřuje na zkoumání existence deficitu v široce definovaném muslimském světě (tj. včetně arabských zemí), a to jak na globální, tak na regionální úrovni.

Článek je rozdělen do šesti sekcí. Navazující druhá sekce formou literární rešerše prezentuje existující studie a výzkumy, které se z různých pohledů zabývají problematikou demokratického deficitu v muslimských zemích. Třetí sekce se zaměřuje na širší teoretický kontext deficitu, když vysvětluje vztah náboženství (islámu) vůči státu a demokracii. Jsou zde také představeny možné příčiny a následně i projevy demokratického deficitu v muslimském světě. Navazující čtvrtá sekce prezentuje metodiku výzkumu a z jeho perspektivy vymezuje pojmy muslimská (islámská) země, muslimský (islámský) svět a Arabský svět. Představena je také konstrukce a výpočet indexu demokracie. Pátá sekce uvádí výsledky výzkumu, které jsou v závěrečné šesté sekci dále diskutovány a shrnuty. Plošné zkoumání demokracie v islámských zemích, tj. neomezení analýzy na jediný re-

\footnotetext{
${ }^{1}$ Mezinárodní organizace, např́íklad Světová banka nebo OSN řadí do Arabského světa 22 států: Alžírsko, Bahrajn, Džibuti, Egypt, Irák, Jemen, Jordánsko, Katar, Komory, Kuvajt, Libanon, Libye, Maroko, Mauritánie, Omán, Palestinská autonomní území, Saúdská Arábie, Somálsko, Spojené Arabské Emiráty, Súdán, Sýrie, a Tunisko.

${ }^{2}$ United Nations Development Programme je rozvojová agentura OSN, jejímž hlavním cílem je pomoci lidem zajistit lepší život.

${ }^{3}$ UNDP vydávají zprávy označeny Arab Human Development Reports (AHDR).

${ }^{4}$ Proto je tento index dále nazýván jako index demokracie, popř. také jako demokratický index.
} 
gion, představuje relativně ojedinělý přístup, nebot mnoho autorů analyzuje pouze jeden region (a to nejčastěji Blízký východ).

\section{Přehled literatury}

Jedním z nejčastěji zmiňovaných faktorů demokratického deficitu v arabských, resp. v islámských zemích, je ekonomický činitel. V mnoha islámských státech lze však více než o faktoru hovořit př́mo o ekonomickém deficitu (viz Kahf 1997), jedná se např. o Afghánistán, Burkinu Faso, Čad, Komory a další islámské země (WB 2019). Životní úroveň představuje důležitý determinant přiklonění země k demokracii (Lipset 1994; Barro 1996; Boldeanu, Constantinescu 2015). Lipset (1994) a později i Barro (1996) pracují s hypotézou, že s ekonomickým rozvojem je úzce spjatý vznik a nárůst vzdělané stř̌ední třídy, která požaduje participaci na politickém dění země a jejíž rostoucí vliv se přetaví v politickou liberalizaci. Je však nutné poznamenat, že ani jeden z autorů nepovažuje ekonomický růst za jediný faktor demokratizace státu. Podle mnohých (Ross 2001; Karatnycky 2002; Elbadawi, Makdisi, Milante 2011; Chaney 2012; Sarkissian 2012) existují další a významnější př́íčiny demokratického deficitu v arabských státech.

Ross (2001) dospěl ve své studii k závěru, že těžba ropy a př́ijmy z ní pocházející potlačují demokracii. Jinými slovy, čím více stát těží a exportuje ropu, tím více je za určitých podmínek náchylnější k nedemokratickému vývoji. Autor navíc zjistil, že ropa škodí demokratickému zř́zení státu více $\mathrm{v}$ chudších zemích než $\mathrm{v}$ bohatších, což má platit nejen pro ropné státy na Blízkém východě, ale také pro země v jiných regionech, které se těší bohatému „nepalivovému“ nerostnému bohatství. Elbadawi, Makdisi a Milante (2011) navíc uvádějí, že státy závislé na primárních zdrojích mnohdy postrádají (efektivní) daňový systém, nevybírají daně od občanů, proto se necítí být povinovány zavádět vưči nim demokratické prvky (např̀. pluralita politických stran, všeobecné volební právo, svobodné shromaždování).

Aktuálnější výzkumy zabývající se vlivem nerostných surovin na úroveň demokracie v zemi již neprokazují zcela negativní efekt. Ačkoliv Ross (2012) výsledky předchozí studie potvrdil, zdůraznil, že ropné bohatství při správném nakládání nemusí být pro stát prokletím, pokud jsou zisky z něj využívány rozumně. Navíc obohatil výzkum o vliv nerostného bohatství na otázku genderu. Vyšší zapojení žen na trhu práce a posílení jejich postavení ve společnosti s sebou přináší demokratizaci. V mnoha rozvojových zemích však ženy pracují v exportně orientovaných odvětvích, službách nebo veřejném sektoru, jejichž možnosti zaměstnávání žen mohou být výrazně negativně ovlivněny nerostným bohatstvím a efektem holandské nemoci. Podle mnohých se ukazuje, že velký vliv na demokracii v daném státě mají sousední země (Brooks, Kurtz 2016; Orihuela 2018). I státy s výraznými nerostnými zdroji budou s velkou pravděpodobností demokratické, pokud sousedí s demokratickými zeměmi.

Další studie uvádějí jako jednu z příčin demokratického deficitu občanské války a arabsko-izraelský konflikt (Sharkansky 1995; Stepan, Robertson 2003; Elbadawi, Makdisi 2007). Zmíněné studie však proklamují, že veškeré negativní efekty vyplývající z izraelsko-arabského konfliktu jsou pouze spojovány s arabskými zeměmi. Konflikt, který trvá již desítky let, ovlivňuje celý region a obzvláště sousední státy Izraele. Řešení konfliktu regionálními mocnostmi a vnější vměšování světových hráčů poskytuje arabským státům kredit pro autoritářské chování. Porušování politických a občanských svobod spolu s vojenskými převraty se stávají ve jménu arabského nacionalismu a podpory Palestiny (Elbadawi, Makdisi, Milante 2011).

Na základě kulturní hypotézy se objevují názory, že arabská kultura a islám jsou neslučitelné s demokratickými hodnotami (Kendourie 1994; Huntington 1996; Fish 2002). Patriarchální uspořádání společnosti společně s kmenovými autoritami brání vzniku demokratickým institucím. Benstead (2014) zjištovala podporu demokracie mezi Araby. Vycházela z teorie, že muslimové 
a ortodoxnější lidé podporující islámské právo, považují demokracii za inkompatibilní s islámem. Teorii rozššřila o poznání, že skupiny tvořící majoritní část společnosti podporují demokracii spíše než minoritní skupiny. Menšinové skupiny křestanů v Palestině či Jordánsku nebo Drúzové v Libanonu se obávají ztráty ochrany, kterou jakožto minorita požívají, v př́ípadě pokud by demokratické volby přivedly islamisty $\mathrm{k}$ moci.

Zajímavou hypotézou vysvětlující demokratický deficit je nízký úhrn srážek (Haber, Menaldo 2011). Autoři předpokládají, že dostatečné srážky v zemědělských regionech vedly k rozvoji oblastí, v nichž se vyvinuly prŕíznivé podmínky pro vznik stabilních demokratických institucí. Chaney (2012) tuto teorii ověřoval na pouštních oblastech Blízkého východu a vztah mezi úhrnem srážek v pouštním terénu a absencí demokracie neprokázal.

Historické dědictví v podobě archaických institucí je také často zmiňováno jako důvod nedostatku demokracie v regionu (Kedourie 1994; Chaney 2012; Benstead 2014). Instituce v regionu se dosud podobají těm, které se nacházely na území dobytých Araby před staletími. Tento pohled přibližuje silné postavení náboženského vůdce jako primární kontroly hlavy státu (Chaney 2012).

Další zmiňované důvody zpo̊sobující demokratický deficit lze souhrnně nazvat jako sociální činitelé. Mezi takové činitele je možné zařadit nedostatečnou úroveň vzdělání či postavení žen ve společnosti (Karatnycky 2002; Fish 2002). Oba autoři se shodují, že problematické postavení žen ve společnosti úzce souvisí s interpretacemi islámu, které ženě přisuzují nižší společenský status, nicméně obě analýzy představují i další faktory potlačující demokracii.

\section{Demokratický deficit v muslimském světě: príčiny a projevy}

V islámu neexistuje rozdíl mezi náboženstvím a státem, protože obě složky jsou součástí islámu, a proto se oba zájmy mají shodovat. Hlavním úkolem státu je ochraňovat společenství věřících a dbát na uplatňování a dodržování islámského práva rovným dílem platným jak pro vládnoucí elity, tak i pro ovládané obyvatele (Kropáček 2011). Avšak v politické praxi se politika státu od náboženství často odděluje a staví se nad něj. Islám pak není hlavním faktorem vnitřní a zahraniční politiky státu, ale slouží pouze jako prostředek manipulace a vysvětlení kroků, které vláda podniká. Z tohoto důvodu jsou často neislámské kroky vlády interpretovány veřejnosti jako islámské, a Západ tak může islám vnímat jako nepřátelský a antidemokratický (Křikavová et al. 2002).

Způsob politické správy není v Koránu pevně stanoven, pouze je zde zmíněno několik morálních principů, které jsou pro politickou vládu relevantní. Avšak základní principy politického uspořádání či jeho struktury se v islámské teologii nevyskytují. Muslimové si tedy mohou zvolit systémy vlády podle svého uvážení, např. staré arabské, perské a turecké politické zvyklosti z předislámského období se staly základní strukturou vlád v období Umajjovců, Abbásovců nebo Osmanů. Zavádění institucionálního uspořádání a přebírání právních norem od jiných společností nebylo považováno za odklon od pravého islámu, proto se v dnešní době lze setkat se sultanátem nebo monarchiemi v islámském světě (Shahin 2015).

\section{Příčiny deficitu v islámských zemích}

V poslední době je zejména na Západě populární teze, že islám je ve své podstatě autoritářský, a tudíž nemůže respektovat základní předpoklady demokracie, tedy důraz na liberalismus a svobodnou volbu (Karatnycky 2002; Elbadawi, Makdisi 2011; Benstead 2014). Na jedné straně se poukazuje na Boha jako na jediného suveréna, na straně druhé v islámu neexistuje náboženská autorita podobná papeži v křestanském světě, takže každý muslim je podle Koránu oprávněn interpretovat si svou víru sám (což samo o sobě nese jistý demokratický potenciál). Nicméně tradicionalisté a fundamentalisté povětšinou trvají na původních výkladech a verzích textů z Koránu, 
takže se k demokracii budou přibližovat jen těžko. Na rozdíl od nich však liberálnější muslimští myslitelé ukázali některé cesty, jak lze islám s demokracií smířit (Karatnycky 2002).

Islám jako náboženství dosud neprošel žádným velkým střetem názorů, jako např́iklad křestanství, je tedy otázkou, zda je islámská reformace (zásadní názorový střet) v konzervativním muslimském světě nevyhnutelná. Několik ideových proudů je však zřejmých: zatímco fundamentalisté lpí na původních výkladech islámu, reformní islamisté prosazují změnu prostřednictvím re-islamizace společnosti se silnou kritikou západních modelů, naopak modernisté budou upřednostňovat modely, které se uplatnily především v západní civilizaci.

Je zřejmé, že nejvyšší autoritou islámu je Korán. Tento text je pro muslimy Božím posláním, původní, jedinou a všeobjímající pravdou, avšak pro politickou organizaci společnosti nedává mnoho pokynů. Z pohledu demokracie zásadními pojmy, které Korán uvádí, jsou šúrá ${ }^{5}$ a idžma. ${ }^{6}$ Navíc islám umožňuje interpretovat texty ve světle moderní doby a vytvářet nové zákony, tento proces je známý jako tzv. idžtihád (Bureš 2002).

Podstata islámu se proto nejeví nutně neslučitelná s podstatou demokracie stejně jako s podstatou jakéhokoli jiného politického systému. Islám obsahuje nadčasové principy fungování společnosti, které však musí být interpretovány v souladu s lokálními a časovými podmínkami dané doby (tedy „ve světle moderní doby“). Islám neupravuje detaily různých situací a nezavádí v nich povinné vzorce chování. Rozhodování ponechává na vůli jednotlivců nebo na shodě společenství, a tak je umožněno rozličným společnostem a národům vytvářet si vlastní zákony (Bureš 2002). Ovšem existují také oponenti kompatibility islámu a demokracie, kteří interpretují různé verše z Koránu antidemokraticky a poukazují na neshodu, nebo dokonce rozpor islámského práva se základními principy lidských práv a demokracie (Bureš 2002; Karatnycky 2002).

Nepřátelské antidemokratické interpretace tvoří jednu z největších překážek pro prosazení demokracie v islámském světě. Jejich cílem je v podstatě legitimizovat (na základě islámu) odpor islámského světa vůči importu „západních“ hodnot, prostřednictvím kterých má uvchtít Západ muslimský svět ovládnout. Existence některých islámských hnutí a svérázných interpretací náboženských texto̊ představují zásadní překážku rozvoje demokracie v islámských zemích.

Samotná Zpráva o arabském lidském rozvoji (AHDR 2004), která definovala demokratický deficit arabských zemí, jako jednu z příčin demokratického deficitu uvádí zájmy velmocí v regionu, které jdou proti podpoře demokracie. Ačkoli tedy západní mocnosti uvalují sankce proti totalitárním vládám, v zemích, kde mají svoje zájmy (např. Saúdská Arábie), nečiní žádné nebo pouze minimální kroky k podpoře změny. Dalšími negativními faktory jsou podle zprávy nedostatečně rozvinutá pro-demokratizační hnutí v regionu, náboženské interpretace, které jsou vůči demokracii nepřátelské nebo „past jednoho zvolení“. Tuto frázi používaly vlády zvláště před Arabským jarem jako výmluvu pro zavedení svobodných voleb a uvolnění politických podmínek, aby tak zamezily př́ípadnému vítězství radikálních islamistů, kteří by pokračovali v totalitární vládě bez demokratických pravidel.

Zahraniční politika západních velmocí se často zaměřovala a někde stále zaměřuje na podporu autoritativních prozápadních elit, které byly mnohdy vnímány jako stabilizační faktor regionu (Dickey, Thomas 2002). Jedná se např́iklad o Egypt za vlády Husního Mubáraka, Saúdskou Arábii nebo Írán za éry posledního šáha. Rozporuplná zahraniční politika Západu se uplatnila i v případě Iráku a jeho bývalého prezidenta Saddáma Husajna. Ten byl v 80. letech 20. století podporován proti šśitskému Íránu, v 90. letech se již stal po okupaci Kuvajtu nepř́ítelem pro Západ, na počátku tisíciletí si vysloužil nálepku „Osa zla“ a v roce 2006 byl popraven (Dickey, Thomas 2002). Jako další př́ílad může být uvedena italská vláda, která za účelem snižování

\footnotetext{
${ }^{5}$ Šúrá představuje konzultace nad zásadními otázkami společnosti. Jedná se o základní prvek demokratické etiky v islámu.

${ }^{6}$ Idžma znamená konsensuální způsob rozhodování.
} 
imigrace na své území udržovala přátelské vazby s Libyí a podporovala jejího tehdejšího vůdce Muammara Kaddáfího. Na podporu přátelství byla v roce 2008 dokonce uzavřena Úmluva o přátelství, partnerství a spolupráci (Sottilotta 2013). Ukazuje se tedy, že vzájemná nedůvěra hraje významnou roli v demokratickém deficitu v regionu a překonání této nedůvěry je zásadním krokem k demokratizaci, budoucí spolupráci a bezkonfliktní a mírové koexistenci.

Podle AHDR jsou další př́ičiny demokratického deficitu zakořeněny ve společenském uspořádání a koloběhu, kdy je vše založeno na diktátu a možnost volby je značně omezená již od útlého dětství. Navíc občané kvůli rentiérskému systému státu nemají zájem na politické participaci. Nejsou nuceni platit daně, žijí v relativní spokojenosti a zároveň nevyvíjejí tlak na vládu, která vůči nim není vedená k zodpovědnosti (AHDR 2004).

Mezi sociální přičiny demokratického deficitu se často řadí podoba školství a vzdělávání v muslimském světě. Tradiční islámské společnosti vyznávají tradiční zpusob života, který zahrnuje i tradiční školství (Cooper, Yue 2008). Stále ještě existují místa, kde se nacházejí pouze islámské školy, a děti jsou tak odkázány na memorování Koránu. Takový způsob výuky nevychovává odborníky do sektorů národních ekonomik a absolventi madras nejsou oporou demokracie. Proto reforma školství, které bude moderní, připravené na nové způsoby komunikací, technologicky pokročilé s volným přístupem ke svobodným informacím, je z hlediska demokracie zásadním předpokladem (Riaz 2016).

Obecně platí, že bohatší společnosti se vzdělanou střední třídou mají větší perspektivu být demokratické. Toto tvrzení však neplatí v ropných státech (např. Saúdská Arábie, Kuvajt, SAE, Brunej), kde občané žijí v blahobytu, bez daňové zátěže, ale také bez motivace podílet se na správě státu. Opakem jsou chudé muslimské země, kde jsou ekonomické př́íjmy podobné jako v jiných rozvojových zemích, kde panuje majetková nerovnost a slabá střední třída pozbývá důležitou funkci - nositele demokracie. Proto je potřeba přistoupit k reformám ekonomik a ekonomických politik států a pracovat na odstranění ekonomických prř́čin deficitu (Pew Research Center 2009).

Nezaměstnanost, kterou jsou postiženy především ženy a mladá populace, může představovat také jednu z prríčin deficitu. U nezaměstnaných, kteří bojují s frustrací z ekonomické inaktivity či přemíry volného času, hrozí následování islámských skupin a postupná radikalizace početné skupiny obyvatelstva. Zásadní roli demokratizace hraje postavení ženy ve společnosti a dalších marginalizovaných skupin, které je třeba zlepšit.

\section{Projevy deficitu v islámských zemích}

I když jsou demokratické prvky obsaženy v islámu, demokracie je v muslimském světě vnímána jako západní konstrukt, proto je k ní přistupováno opatrně až odmítavě, a je neustále podrobována řadě zkoumání a pochybností (Hamid 2011). V takovém případě je zcela zřejmé, že rozdíl demokratičnosti islámského světa a ostatních zemí je podle organizace Freedom House dramatický. Muslimské země se např́ič regiony potýkají s obdobnými problémy, kvůli nimž je demokracie narušována.

Jeden z problémů mohou představovat volby, které mají zabezpečit demokratické střídání moci dle preferencí voličủ. Konání voleb v zemi však není vždy zárukou demokracie. Často jsou opoziční politické strany perzekuovány, zastrašovány a mnohdy kvůli neférovému průběhu voleb opozice nekončí úspěšně. V některých případech se kandidáti do samotných voleb ani nedostanou, protože jsou z kandidatury vyřazeni státním kontrolním orgánem pro nejrůznější důvody, jak se tomu děje např́iklad v Íránu. Za nečestné jsou mnohdy označovány volby ve střední Asii, kde vládní strany a jejich představitelé zastávají stejné funkce desetiletí (např. Tádžikistán). Do tzv. Arabského jara se nestř́idaly ani hlavy států na Blízkém východě, a tak Tunisko, Egypt, Libye či Jemen měli stejného prezidenta (v př́ípadě Libye se užívalo označení vůdce) i více než 20 let (Puddington et al. 2014). Avšak i v muslimských zemích existují kladné příklady. V arabských zemích zasažených 
masovými protivládními demonstracemi se změnili prezidenti, avšak nové uspořádání států nedokázalo mnohdy nasměrovat země $\mathrm{k}$ demokratickému vývoji. Pouze Tunisko se stalo jediným úspěšným výsledkem tzv. Arabského jara a od organizace Freedom House si za to vysloužilo nálepku demokratické země. Úspěšné reformy volebních systémů se podařily například v Sierra Leone, Senegalu nebo Kosovu, kde se následně konaly demokratické volby.

Kromě politické opozice jsou v některých státech pronásledováni novináři či občanští aktivisté. Kritiku organizace Freedom House za zhoršování svobod, potlačování občanských aktivistů a novinářů si vysloužily Maroko a Kuvajt, které jsou organizací označeny jako částečně svobodné země (Puddington et al. 2014, 2015, 2018). Také Bangladéš byl kritizován za právní obtěžování bloggerů či Maledivy za nesvobodu vyjadřování. Stíhání a omezení činnosti se netýká pouze novinářu a občanských aktivistů, ale pronásledováni či pod výraznou státní kontrolou mohou být i př́slušníci nevládních a mezinárodních organizací. Například Indonésie byla kritizována z důvodu přijetí zákona, který omezuje aktivity nevládních organizací, zvyšuje nad nimi byrokratický dohled a vyžaduje, aby dodržovaly národní ideologii. Ženy, obzvláště ty ve vrcholných pozicích, se také mohou ocitnout pod státním drobnohledem, stát se obětmi zastrašování či jako aktivistky v Saúdské Arábii skončit ve vězení za šíření svých názorů (Puddington et al. 2018).

Lidé tvořící minoritu společnosti jsou v mnohých muslimských zemích také perzekuováni. Často jsou v nebezpečí členové LGBT komunity, a to např́íklad v Malajsii, Afghánistánu, Íránu, Gambii nebo v Saúdské Arábii, nebo vyznavači odlišné větve islámu či zcela jiného náboženství. Š́íité zažívají útoky ve státech Perského zálivu, Bangladéši nebo v Malajsii, křestané v Egyptě, a náboženským útokům se nevyhnou ani muslimové žijící v nemuslimských státech (např. Indie, Myanmar) (Puddington et al. 2017, 2018).

Snahy o demokracii v muslimských zemích výrazně negativně ovlivňuje nestabilní bezpečnostní situace, konflikty, vojenské převraty nebo stahování zahraničních vojáků hlídajících bezpečnost. Nezřídka vlády států procházející bezpečnostní krizí využívají nastalou situaci ve svůj prospěch v podobě např. vyhlášení či prodloužení stavu nouze, při kterém jsou záměrně potlačována lidská práva. V severní Africe válečný konflikt v Libyi destabilizuje sousední státy Tunisko a Egypt, stahování vojsk NATO v Afghánistánu výrazně zhoršilo bezpečnostní situaci humanitárním pracovníkům, ženám zastávajícím veřejné funkce a obyvatelům země obecně. Se zhoršením bezpečnosti se potýká i Burkina Faso, kde místní armáda sesadila parlament. Velkou bezpečnostní hrozbu a současně i ohrožení demokracie představují militantní a teroristické organizace, např. tzv. Islámský stát, Hamás nebo Boko Haram.

Překážkou demokratického uspořádání státu může být charakter státní ekonomiky. S tímto problémem se potýkají tzv. rentiérské státy, jejichž př́ijem je z větší části tvořen těžbou nerostných surovin. Tyto státy často postrádají demokratické vlády. V zájmu udržení se u moci nejsou mnohdy přijímána nepopulární opatření (např. výběr daní), díky kterým by se obyvatelstvo cítilo oprávněno vyžadovat demokratické prvky (např. v podobě voleb).

Podle dat organizace Freedom House lze konstatovat, že islámské země mají tendenci k demokratickému deficitu. Nejlepších výsledků dosáhly muslimské země na počátku měření v roce 1973. Výsledky z tohoto roku ukázaly, že ze všech nesvobodných zemí bylo „pouze“ $35 \%$ islámských, a naopak mezi svobodnými zeměmi bylo $6 \%$ islámských. O deset let později opět třetinu nesvobodných zemí tvořily islámské státy, ale žádný z nich nezískal status svobodné země. Od roku 2003 tvoří islámské země více než polovinu všech nesvobodných zemí světa ( $54 \%$ v roce 2019 ) a pouze jednotky procent představují svobodné země (2\% v roce 2019$)$. 


\section{Metodika výzkumu}

Tato studie se zaměřuje zejména na zkoumání existence demokratického deficitu v široce definovaném muslimském světě, který zahrnuje i Arabský svět. Pro účely větší části tohoto výzkumu, pokud není uvedeno jinak, je možné Arabský svět vnímat jako podmnožinu muslimského světa. V některých částech se však výzkum zabývá ověřením existence demokratického deficitu v Arabském světě. $\mathrm{V}$ těchto částech je Arabský svět z muslimského světa vydělen a srovnáván s ostatními (tj. nearabskými) muslimskými zeměmi.

Muslimský, resp. islámský svět je v této práci definován jako soubor muslimských zemí, tj. zemí s $50 \%$ a větším podílem muslimů z celkového počtu obyvatel. ${ }^{7}$ Celkem lze podle tohoto př́istupu označit 50 zemí světa za muslimské, z toho jich patří 22 do Arabského světa (viz Tabulka 1). Arabským světem se ve studii rozumí soubor arabských zemí. Část studie se také zaměřuje na zkoumání existence demokratického deficitu muslimských zemí v rámci jednotlivých světových regionů. Ty jsou definovány v souladu s př́stupem Světové banky ${ }^{8}$ jako východní Asie a Pacifik, Evropa a střední Asie, Blízký východ a severní Afrika, jižní Asie, a subsaharská Afrika.

Ke kvantifikaci demokratického deficitu muslimských a arabských zemí byl navržen složený index, který měří výkon jednotlivých zemí světa v oblasti demokracie. Proto je tento index v dalším textu označován jako demokratický index, resp. index demokracie. Demokratický deficit je pak vyjádřen jako rozdíl mezi průměrnými hodnotami indexu srovnávaných skupin zemí (např́klad mezi muslimskými a nemuslimskými zeměmi). Index je složen ze tří komponent (osobní práva, osobní svobody, rovné zacházení a absence diskriminace) a každá komponenta je reprezentována čtyřmi indikátory. Jednotlivé komponenty reflektují př́stup AHDR (2004) k demokratickému deficitu. Složení indexu je prezentováno v Tabulce 2 a prrístup AHDR je blíže popsán v př́loze 1, stejně jako další zvažované indikátory, které ve finálním indexu nakonec nebyly použity.

Výsledný demokratický index byl zkonstruován s využitím několika statistických metod. Korelační analýza ověřuje souvislost mezi jednotlivými indikátory, které jsou zahrnuty v jedné konkrétní komponentě indexu. Existence jednoho společného základního faktoru v rámci každé komponenty indexu je ověřována pomocí analýzy základních komponent, resp. faktorové analýzy (principal component analysis, $\mathrm{PCA}$, resp. principal component-factor, $\mathrm{PCF}$ ). $\mathrm{PCA} / \mathrm{PCF}^{9}$ je také používána pro stanovení vah jednotlivých indikátorů v rámci každé komponenty indexu. Komponenty jsou pak do hodnoty indexu agregovány prostřednictvím prostých aritmetických průměrů. Kromě PCA/PCF metody se vhodnost jednotlivých indikátorů, kterých je v indexu celkem dvanáct, testuje prostřednictvím Cronbachovy alfy ${ }^{10}$ a $\mathrm{KMO}^{11}$ analýzy. Výsledky těchto testů

\footnotetext{
${ }^{7}$ Existují další možné př́istupy vymezení islámského světa, například na základě členství v Organizaci islámské spolupráce (OIC), v níž se nachází 57 členských států. Kromě 50 islámských zemí využitých v této studii je členem OIC také např. Guyana, Uganda nebo Togo s nízkým podílem muslimského obyvatelstva na celkovém obyvatelstvu země (OIC 2020).

${ }^{8}$ Metodika instituce Světové banky byla zvolena proto, že AHDR také využívají regiony vymezené Světovou bankou. Dva regiony (Latinská Amerika a Karibik, Severní Amerika) nebyly zařazeny, nebot se v těchto regionech nenacházejí země definované jako muslimské. Netradiční sloučení Evropy a střední Asie do jednoho světového regionu je ve studii ponecháno z důvodu konzistentního př́stupu vůči Světové bance, který je využit v AHDR.

${ }^{9}$ Tato metoda testuje, jestli korelované indikátory mají v rámci konkrétní komponenty společný základ (základní komponentu), jinými slovy jestli jsou dostatečně podobné pro měření společného fenoménu na úrovni komponenty. Podmínka existence jednoho faktoru je ve studii splněna.

${ }^{10}$ Cronbachova alfa (Cronbach's alpha) udává míru vnitřní konzistence mezi indikátory v rámci jednotlivých komponent. Empirické pravidlo udává, že hodnota této statistiky by měla být větší než 0,7 pro jakékoliv validní seskupení proměnných (Bland, Altman 1997). Pravidlo bylo v analýze splněno.

${ }^{11}$ Kaiser-Meyer-Olkinova (KMO) analýza měří vhodnost seskupení indikátorů pro faktorovou analýzu. Podle empirického pravidla by mělo platit, že hodnoty průměrné KMO míry jsou vyšší než 0,5. Taková hodnota KMO potvrzuje, že indikátory sdružené do dané komponenty vhodně odrážejí její základní koncept (Manly 2004). Tato podmínka byla u všech komponentů indexu splněna.
} 
Tabulka 1: Seznam muslimských a arabských zemí

\begin{tabular}{|c|c|c|c|}
\hline Země & $\begin{array}{l}\text { Podíl muslimů na } \\
\text { celkové populaci (\%) }\end{array}$ & Země & $\begin{array}{l}\text { Podíl muslimů na } \\
\text { celkové populaci (\%) }\end{array}$ \\
\hline Afghánistán & 99,8 & Saúdská Arábie* & 92,1 \\
\hline Somálsko* & 99,8 & Súdán* & 91,2 \\
\hline Maroko* & 99,7 & Senegal & 90,8 \\
\hline Tunisko* & 99,5 & Egypt* & 90,4 \\
\hline Západní Sahara ${ }^{12}$ & 99,4 & Bangladéš & 88,8 \\
\hline Jemen* & 99,1 & Gambie & 88,6 \\
\hline Mauritánie* & 99,1 & Omán* & 88,1 \\
\hline Írán & 98,8 & Guinea & 86,6 \\
\hline Mayotte & 98,8 & Mali & 86,6 \\
\hline Alžírsko* & 98,5 & Kuvajt* & 86,2 \\
\hline Maledivy & 98,4 & Katar* & 83,6 \\
\hline Komory* & 98,3 & Kyrgyzstán & 83,4 \\
\hline Turecko & 98,3 & Palestina* & 80,7 \\
\hline Irák* & 98,2 & Bahrajn* & 79,5 \\
\hline Džibuti* & 96,9 & Indonésie & 79,3 \\
\hline Libye* & 96,6 & Spojené arabské emiráty* & 76,6 \\
\hline Tádžikistán & 96,4 & Kazachstán & 68,8 \\
\hline Pákistán & 96,3 & Sierra Leone & 64,6 \\
\hline Niger & 95,4 & Albánie & 61,6 \\
\hline Turkmenistán & 95,2 & Libanon* & 61,1 \\
\hline Ázerbájdžán & 95,1 & Brunej & 57 \\
\hline Jordánsko* & 94,5 & Malajsie & 56,4 \\
\hline Uzbekistán & 94,2 & Čad & 56,2 \\
\hline Sýrie* & 93,8 & Burkina Faso & 54,1 \\
\hline Kosovo & 93,1 & Eritrea & 51,6 \\
\hline
\end{tabular}

Zdroj: Grim, Johnson, Skirbekk, Zurlo (2015).

Pozn.: Země označené symbolem * představují země tzv. Arabského světa vymezené organizací UNDP

a Světovou bankou.

a korelace mezi indikátory v rámci komponent indexu jsou uvedeny v př́loze 3,4 a 5 . Vypočítané hodnoty indexu jsou dále analyzovány pomocí metod deskriptivní statistiky a regresní analýzy.

Hodnoty indexu demokracie byly vypočítány pro většinu zemí světa (dle dostupnosti vstupních dat) pro tři časová období 1998-2000, 2008-2010 a 2016-2018. Z těchto období také pochází vstupní hodnoty jednotlivých indikátorů, ze kterých se index skládá. V každém období je z hodnot za jednotlivé roky vypočítán aritmetický průměr, aby se snížila potenciální fluktuace a také nedostupnost dat. Tyto průměry pak vstupují jako raw data do výpočtu indexu.

Finální kalkulace indexu demokracie vzniká tak, že se nejdříve tzv. min-max metodou ${ }^{13}$ převedou (již transformované) ${ }^{14}$ hodnoty jednotlivých indikátorů na skóre 0-100, kde 100 je nejlepší

\footnotetext{
12 Západní Sahara není Světovou bankou klasifikována jako samostatné území.

${ }^{13}$ Tzv. min-max metoda je často použivaná metoda standardizace různě měřených proměnných, aby byly vzájemně srovnatelné, a to např́klad na škále 0-100 bodů. Vypočítá se následujícím způsobem pro každé pozorování každé proměnné: od hodnoty konkrétního pozorování se odečte minimální hodnota dané proměnné, následně se tento rozdíl vydělí rozdílem mezi maximální a minimální hodnotou této proměnné.

${ }^{14}$ Transformovanými hodnotami se myslí hodnoty, které jsou standardizované na z-scores (a které, pokud to bylo třeba, byly předtím zlogaritmovány a invertovány).
} 
Tabulka 2: Index demokratického deficitu

\begin{tabular}{|c|c|c|}
\hline & Komponenta indexu & Indikátory (v závorce je uveden zdroj dat) \\
\hline \multirow{12}{*}{ 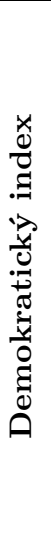 } & \multirow{4}{*}{ Osobní práva } & Politická práva (Freedom House) \\
\hline & & Přístup ke spravedlnosti (V-Dem) \\
\hline & & Úroveň právního státu (WGI) \\
\hline & & Vlastnická práva (V-Dem) \\
\hline & \multirow{4}{*}{ Osobní svobody } & Svoboda vyjadřování (V-Dem) \\
\hline & & Svoboda vyznání (V-Dem) \\
\hline & & Vnímání korupce (WGI) \\
\hline & & Osobní autonomie a individuální práva (Freedom House) \\
\hline & \multirow{4}{*}{$\begin{array}{l}\text { Rovné zacházení } \\
\text { a absence diskriminace }\end{array}$} & Diskriminace a násilí vůči menšinám (FSI) \\
\hline & & Index rovnoměrného rozdělení zdrojů (V-Dem) \\
\hline & & Rovnost politické moci sociálních skupin (V-Dem) \\
\hline & & Rovnost politické moci podle socioekonomického postavení (V-Dem) \\
\hline
\end{tabular}

Zdroj: vlastní zpracování.

možný výsledek (odrážející nejlepší pozorovanou hodnotu daného indikátoru v datasetu) a 0 je nejhorší možný výsledek (reflektující nejhorší pozorovanou hodnotu daného indikátoru v datasetu). ${ }^{15}$ Skóre každé komponenty se vypočítá jako vážený průměr skóre jednotlivých indikátorů, kde váhy jsou určeny statistickou metodou (PCF). Výsledné hodnoty indexu demokracie se pak vypočítají jako prostý aritmetický průměr tří komponent (osobní práva; osobní svobody; rovné zacházení a absence diskriminace). Získané hodnoty měří výkon jednotlivých zemí v oblasti demokracie v uvedených třech obdobích.

Těchto hodnot lze ale využít také k analýze demokratického deficitu muslimských, resp. arabských zemí, nebot deficit je v tomto kontextu definován jako (statisticky významný) rozdíl mezi (průměrnými) hodnotami indexu srovnávaných skupin zemí. V př́padě demokratického deficitu muslimských zemí je zkoumán rozdíl mezi průměrnými hodnotami muslimských (tj. včetně arabských) a nemuslimských zemí. Pro ověření existence demokratického deficitu arabských zemí je srovnávána průměrná hodnota indexu pro arabské země vưči průměrné hodnotě indexu pro ostatní (tj. nearabské) muslimské země. Průměry používané pro srovnávání skupin zemí (a tedy i k identifikaci demokratického deficitu) jsou nevážené (tj. nejsou vážené populací jednotlivých zemí).

Ke srovnávání průměrných hodnot zemí je využito metody regresní analýzy s tzv. dummy proměnnou. Tato dichotomická proměnná, která nabývá pouze hodnot 1 a 0 , vymezuje srovnávané skupiny zemí. Závislou proměnnou v regresní analýze jsou vždy hodnoty indexu demokracie pro jednotlivé země. Regresní koeficient u dummy proměnných tak ukazuje rozdíl v průměrných hodnotách indexu mezi srovnávanými skupinami zemí, tedy v podstatě měří demokratický deficit.

Další výhodou řešení tohoto problému regresní analýzou s dummy proměnnými je relativní snadnost přidání kontrolních proměnných. Jako kontrolní proměnná je v regresi použita ekonomická úroveň, měřená hrubým národním důchodem (HND) na obyvatele (v běžných USD a podle konverze metodou Atlas). Hodnoty pro tuto proměnnou jsou konstruovány jako tř́letý průměr, který vždy částečně (o jeden rok) předchází časová období měřená indexem demokracie,

\footnotetext{
${ }^{15}$ Při konstrukci složených indexů se často využívají tzv. utopie (nejlepší možná dosažitelná hodnota, tj. best-case scenario) a dystopie (nejhorší možná dosažitelná hodnota, tj. worst-case scenario). Předkládaný index těchto přístupů nevyužívá, a to proto, že v této studii jde zejména o srovnání hodnot mezi zeměmi, a nikoliv o srovnávání vývoje např́klad vzhledem k určitým stanoveným cílům.
} 
Graf 1: Porovnání indexu demokracie v Arabském světě, ostatních muslimských a nemuslimských zemích

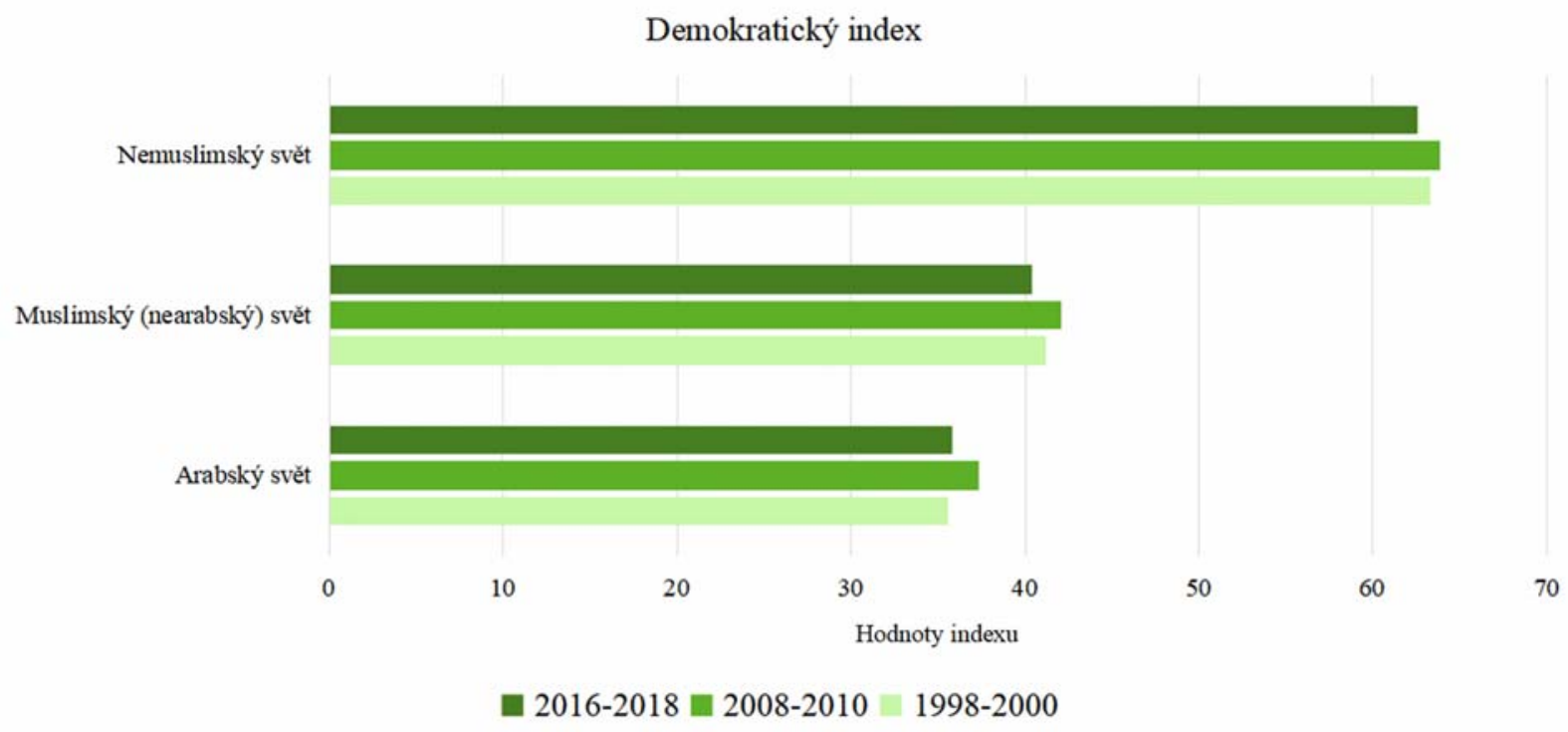

Zdroj: vlastní zpracování.

což do určité míry řeší i problém potenciální endogenity vztahu mezi ekonomickou úrovní a úrovní demokracie.

\section{Výsledky analýzy demokratického deficitu muslimských a arabských zemí}

Tato část studie je zaměřena na popis a analýzu výsledků. Nejprve jsou zkoumány a porovnány průměrné hodnoty indexu pro Arabský, muslimský a nemuslimský svět, následně je ilustrován a komparován vývoj indexu demokracie v čase v jednotlivých světových regionech, a to zvlášt pro muslimské a nemuslimské státy.

Graf 1 srovnává průměrné hodnoty indexu demokracie pro Arabský svět, ostatní muslimské země (bez arabských) a nemuslimské země ve všech třech sledovaných obdobích. Tato komparace přináší vcelku zajímavá zjištění. Zatímco mezi prvními dvěma obdobími průměrná hodnota indexu demokracie pro všechny tři kategorie zemí vzrostla, došlo naopak mezi druhým a třetím obdobím k poklesu hodnot indexu ve všech skupinách. Nejlepších výsledků v indexu demokracie dosahují nemuslimské země. Porovnání výsledků arabských zemí a ostatních muslimských států odhaluje výrazně horší výkon arabských států ve všech sledovaných obdobích. Zatímco pro muslimské nearabské země se hodnoty indexu pohybují v průměru kolem 41, v Arabském světě situaci na poli demokracie nezlepšilo ani tzv. Arabské jaro. Před jeho vypuknutím (druhé sledované období) hodnota indexu přesahovala 37, avšak ve třetím období, tedy po Arabském jaru, hodnota indexu klesla na 35,79. Je zcela zřejmé, že obě skupiny zaostávají za nemuslimskými státy, což naznačuje možnou existenci demokratického deficitu. Lze navíc konstatovat, že za téměř dvacet let se úroveň demokracie $\mathrm{v}$ analyzovaných regionech téměř nezměnila - to ovšem platí také pro nemuslimský svět!

Pohled na výsledky jednotlivých států ukazuje, že v Arabském světě měl nejnižší hodnotu indexu v prvním období Súdán $(7,97)$, ve druhém období Somálsko $(9,18)$ a ve třetím období Sýrie (3,72). Naopak nejlepších výsledků dosáhl v prvních dvou obdobích Kuvajt $(58,75$ a 57,25), ve třetím období ho přeskočilo Tunisko $(69,10)$. V muslimském světě (bez arabských zemí) skončil v prvním období nejhưře Afghánistán $(9,87)$ a nejlépe Senegal $(65,18)$, v druhém období nejhůře 
Graf 2: Vývoj indexu demokracie v muslimských a nemuslimských zemích světových regionů

\section{Demokratický index v regionech}

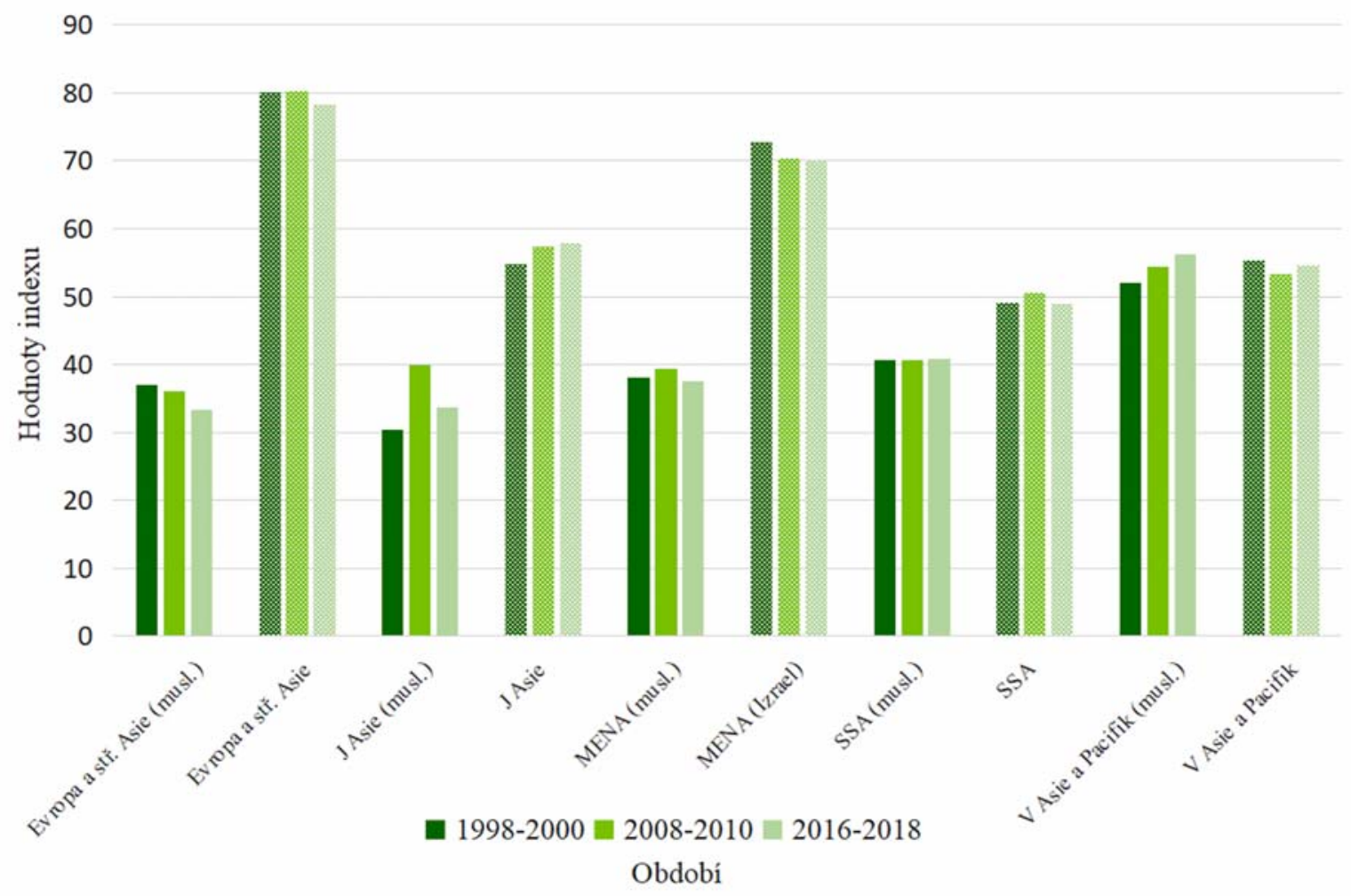

Zdroj: vlastní zpracování.

dopadl Turkmenistán $(13,23)$ a nejlépe opět Senegal $(63,83)$, což platilo i v posledním období: Turkmenistán zůstal poslední $(11,34)$ a Senegal první $(68,63)$.

Graf 2 srovnává průměrné hodnoty indexu demokracie pro muslimské a nemuslimské státy v jednotlivých světových regionech (definovaných Světovou bankou) ve třech zkoumaných obdobích (1998-2000; 2008-2010; 2016-2018). Z grafu je patrné, že lepších výsledků v oblasti demokracie dosáhly nemuslimské státy regionů s výjimkou východní Asie a Pacifiku. V tomto regionu to byly ve druhém a třetím období muslimské země, které zaznamenaly v průměru vyšších hodnot indexu demokracie (o 1 až 2 body). Zajímavostí také je, že muslimské země tohoto regionu, společně s nemuslimskými zeměmi jižní Asie, zaznamenaly odlišný trend vývoje indexu. Zatímco $\mathrm{v}$ obou zmíněných regionech došlo $\mathrm{v}$ průměru $\mathrm{k}$ nárůstu indexu demokracie, ve zbývajících regionech se hodnoty v čase snížily.

Regionem s vůbec nejnižší úrovní demokracie je muslimská jižní Asie v závěsu s muslimskými státy Evropy a střední Asie, naopak nejlepších výsledků dosáhly nemuslimské státy Evropy a střední Asie. Pokud jde o individuální země, celkově nejhorších výsledků v jednotlivých obdobích dosáhly muslimské země Súdán, Somálsko a Sýrie (viz výše). Naopak nejlépe hodnocenou zemí v prvním a druhém období se stalo Norsko $(99,53$ a 98,82), které bylo ve třetím období nahrazeno Finskem $(96,96)$.

Dosavadní výsledky a grafy naznačují existenci demokratického deficitu jak všech muslimských zemí vůči nemuslimským, tak arabských zemí vůči ostatním muslimským. Tato zjištění je však nutné ověřit dalšími analýzami, například pomocí regrese. Závislou proměnnou je ve všech re- 
Tabulka 3: Demokratický deficit $v$ muslimských a arabských zemích

\begin{tabular}{|c|c|c|c|c|}
\hline \multicolumn{5}{|c|}{ Závislá proměnná: index demokracie } \\
\hline & model 1 & model 2 & model 3 & model 4 \\
\hline \multirow{2}{*}{ Muslimské země } & $-24,36 * * *$ & $-18,43^{* * *}$ & & \\
\hline & $(1,71)$ & $(1,73)$ & & \\
\hline \multirow{2}{*}{ Arabské země } & & & $-4,99 *$ & $-6,18^{* *}$ \\
\hline & & & $(2,60)$ & $(3,07)$ \\
\hline \multirow{2}{*}{ ln_HND } & & $8,06^{* * *}$ & & $2,17^{* *}$ \\
\hline & & $(0,42)$ & & $(1,00)$ \\
\hline Koef. determinace $\mathbf{R}^{2}$ & 0,23 & 0,55 & 0,03 & 0,44 \\
\hline Počet pozorování & 509 & 500 & 135 & 129 \\
\hline
\end{tabular}

Zdroj: vlastní zpracování.

Pozn.: uvedeny jsou regresní koeficienty, v závorce jsou směrodatné chyby robustní vůči heteroskedasticitě. Regresní koeficienty jsou významné na: *** $1 \%$ hladině, ** $5 \%$ hladině, * $10 \%$ hladině. Koeficient determinace $\mathrm{R}^{2}$ nabývá hodnot od nuly do jedné a udává, jak velká část variability závislé proměnné (tedy skóre demokratického indexu) byla modelem vysvětlena. Modely 1 a 2 srovnávaly muslimské země (vč. arabských) a nemuslimské země. Modely 3 a 4 srovnávaly arabské země vůči ostatním muslimským (tj. nearabským) zemím. Proto je v modelech 3 a 4 výrazně nižší počet pozorování.

gresních analýzách index demokracie. Vysvětlujícími proměnnými jsou dichotomické (dummy) proměnné, které vymezují srovnávané skupiny zemí. Regresní koeficient u dummy proměnných ukazuje rozdíl v průměrných hodnotách indexu mezi srovnávanými skupinami zemí, tedy v podstatě měří demokratický deficit.

Výhodou metody regresní analýzy oproti jiným alternativním metodám (srovnání průměrných hodnot pomocí t-testů, popř. analýza rozptylu) je snadné přidání kontrolních proměnných. V této analýze je kontrolována ekonomická úroveň států pomocí ukazatele HND na obyvatele, aby byla vyloučena možnost, že demokratický deficit je do značné míry pouze důsledek rozdílné ekonomické úrovně skupin zemí. Kontrola ekonomické úrovně se jeví jako nezbytná také s ohledem na malé a bohaté ropné státy Perského zálivu. ${ }^{16}$

Výsledky první sady regresních analýz jsou shrnuty v tabulce 3. Modely 1 a 2 ověřují existenci demokratického deficitu všech muslimských zemí (tj. včetně arabských) vưči nemuslimským zemím. Toho je dosaženo srovnáním průměrných hodnot demokratického indexu muslimských a nemuslimských zemí, přičemž hodnota regresního koeficientu dummy proměnné pro muslimské země přímo naznačuje rozsah deficitu. Model 2 navíc kontroluje ekonomickou úroveň států. Z tabulky 3 je zřejmé, že demokratický deficit muslimských zemí (tj. rozdíl v hodnotě průměrného skóre demokratického indexu mezi muslimskými a nemuslimskými zeměmi) činí 24,36 bodů. Pokud je však v regresní analýze kontrolována ekonomická úroveň, deficit se sníží na 18,43 bodů. Oba tyto výsledky jsou navíc statisticky významné na $1 \%$ hladině.

Oba modely tak potvrzují výrazný a statisticky významný demokratický deficit muslimských zemí. Je však patrné, že přidáním ekonomické proměnné se rozvojový deficit sníží, zůstává však značný a statisticky významný. To naznačuje, že menší část demokratického deficitu muslimských zemí lze vysvětlit jejich nižší ekonomickou úrovní. Zároveň platí, že s vyšší ekonomickou úrovní se zvyšují hodnoty demokratického indexu jak muslimských, tak nemuslimských zemí (i tento výsledek je statisticky významný na $1 \%$ hladině).

\footnotetext{
${ }^{16} \mathrm{Na}$ základě kontroly funkční formy vztahů mezi hodnotami indexů a HND na obyvatele, která proběhla před samotnými regresemi, vstupuje HND na obyvatele do všech regresí v logaritmicky transformované podobě (proto je v tabulkách uváděna zkratka ln_HND, kde ln_ značí přirozený logaritmus).
} 
Tabulka 4: Vývoj deficitu v muslimských zemích

\begin{tabular}{|c|c|c|c|c|c|c|}
\hline \multicolumn{7}{|c|}{ Závislá proměnná: index demokracie } \\
\hline & $\begin{array}{c}\text { model } 1 \\
(1998-2000)\end{array}$ & $\begin{array}{c}\text { model } 2 \\
(2008-2010)\end{array}$ & $\begin{array}{c}\text { model } 3 \\
(2016-2018)\end{array}$ & $\begin{array}{c}\text { model } 4 \\
(1998-2000)\end{array}$ & $\begin{array}{c}\text { model } 5 \\
(2008-2010)\end{array}$ & $\begin{array}{c}\text { model } 6 \\
(2016-2018)\end{array}$ \\
\hline Muslimské země & $\begin{array}{c}-24,74 * * * \\
(2,90)\end{array}$ & $\begin{array}{c}-24,00 * * * \\
(2,89)\end{array}$ & $\begin{array}{c}-24,34^{* * * *} \\
(3,11)\end{array}$ & $\begin{array}{c}-18,38 * * * \\
(0,68)\end{array}$ & $\begin{array}{c}-18,25^{* * *} \\
(2,90)\end{array}$ & $\begin{array}{l}-17,34 \\
(3,20) \\
\end{array}$ \\
\hline $\ln \_$HND & & & & $\begin{array}{c}8,90 * * * \\
(2,98)\end{array}$ & $\begin{array}{l}8,59^{* *} \\
(0,72)\end{array}$ & $\begin{array}{c}8,79 * * * \\
(0,85)\end{array}$ \\
\hline Koef. determinace $\mathbf{R}^{2}$ & 0,23 & 0,23 & 0,22 & 0,62 & 0,58 & 0,53 \\
\hline Počet pozorování & 168 & 170 & 171 & 165 & 167 & 168 \\
\hline
\end{tabular}

Zdroj: vlastní zpracování.

Pozn.: uvedeny jsou regresní koeficienty, v závorce jsou směrodatné chyby robustní vůči heteroskedasticitě. Regresní koeficienty jsou významné na: *** $1 \%$ hladině, ** $5 \%$ hladině, * $10 \%$ hladině. Koeficient determinace $\mathrm{R}^{2}$ nabývá hodnot od nuly do jedné a udává, jak velká část variability závislé proměnné (tedy skóre demokratického indexu) byla modelem vysvětlena.

Modely 3 a 4 v tabulce 3 porovnávají úrovně demokracie mezi arabskými a ostatními muslimskými zeměmi. I zde platí, že hodnota regresního koeficientu pro dummy proměnnou pro arabské země př́mo naznačuje rozsah demokratického deficitu arabských zemí vůči ostatním (nearabským) muslimským zemím. Zatímco bez kontroly ekonomické úrovně (model 3) byl deficit menší a statisticky méně významný, při kontrole HND na obyvatele (model 4) deficit dokonce vzrostl v neprospěch arabských zemí. To však není úplně překvapivé, nebot řada států Arabského světa je ekonomicky velmi bohatá, a proto se jejich pozice při kontrole ekonomické úrovně může relativně zhoršit. To ostatně výsledky ukazují, nebot demokratický deficit při kontrole ekonomické úrovně vzrostl o 1,19 bodu indexu v neprospěch arabských zemí, navíc se výsledek stal statisticky významnějším (na $5 \%$ hladině).

Druhá sada regresních analýz (viz Tabulka 4) zkoumá vývoj demokratického deficitu muslimských zemí (včetně arabských; oproti nemuslimským) v čase, tedy pro jednotlivá tři časová období. Z výsledků je zřejmé, že demokratický deficit je v čase spíše konstantní - neprohlubuje se, ale ani nedochází k jeho snižování. Tento závěr platí podobně jak pro případy, kdy není ekonomická úroveň kontrolována (modely 1 až 3), tak pro př́ípady s její kontrolou (modely 4 až 6). Pokud jde o modely bez kontroly ekonomické úrovně, výraznější snížení demokratického deficitu muslimských zemí nastalo mezi prvními dvěma obdobími, kdy se deficit snížil o 0,74 bodu indexu. Ve třetím období se oproti druhému deficit naopak nepatrně prohloubil, a to o 0,34 bodu. V modelech s kontrolou ekonomické úrovně činil v prvním období demokratický deficit muslimských zemí 18,38 bodů, v posledním období se deficit snížil na 17,34 bodů. Z výsledků je patrné, že za posledních přibližně 20 let nedošlo v podstatě k žádnému snížení demokratického deficitu muslimských zemí. Hlavním důvodem přetrvávajícího demokratického deficitu muslimských zemí je jejich stagnující výkon v oblasti demokracie, což demonstrují nezlepšující se hodnoty demokratického indexu těchto zemí. Pro doplnění lze uvést, že demokratický deficit Arabského světa se vůči ostatním muslimským zemím v čase mírně snižuje. Tyto regresní analýzy však nejsou statisticky průkazné, což je do značné míry důsledek výrazně nižšího počtu pozorování v jednotlivých modelech (tyto výsledky jsou uvedeny v př́loze 6).

Poslední část výzkumu byla zaměřena na regionální perspektivu demokratického deficitu muslimských zemí. Tato analýza však ve světle již prezentovaných výsledků překvapivé závěry nepřinesla. Demokratický deficit byl potvrzen ve všech regionech a faktem zůstává, že muslimské země zaostávají za nemuslimskými zeměmi významně i v př́ípadě, kdy je kontrolována ekonomická 
úroveň států (jedinou výjimkou je region jižní Asie). Lze navíc konstatovat, že vývoj deficitu v čase se př́liš nemění, jinými slovy muslimským státům se ani v jednotlivých regionech nedaří demokratický deficit snižovat. Nejhlubší demokratický deficit muslimských zemí byl indikován v regionu Blízkého východu, tento výsledek však nemá velkou vypovídající hodnotu, nebot jedinou porovnávanou nemuslimskou zemí je Izrael. Druhý největší demokratický deficit muslimských zemí byl zjištěn pro region Evropy a střední Asie (výsledek v průměru o 26 bodů horší u muslimských zemí). Naopak nejnižší demokratický deficit se projevil v regionu subsaharské Afriky (rozdíl činil pouhé 4 body indexu demokracie v neprospěch muslimských států).

\section{Diskuze výsledků a závěr}

Existence demokratického deficitu v muslimských, resp. arabských zemích, byla zkoumána prostřednictvím konstrukce a výpočtu indexu demokracie. Tento index z hlediska struktury vychází ze Zprávy o arabském lidském rozvoji, který demokratický deficit pro arabské země definoval (AHDR 2004). Index se skládá z celkem tří komponent (osobní práva; osobní svobody; rovné zacházení a diskriminace), z nichž každá obsahuje čtyři indikátory. Hodnoty indikátorů pro jednotlivé země byly agregovány do skóre příslušných komponent jako vážený průměr indikátorů v dané komponentě, přičemž váhy byly stanoveny statisticky metodou PCF. Výsledné hodnoty indexu pro jednotlivé země pak byly vypočítány jako prostý aritmetický průměr skóre jednotlivých komponent. Hodnoty indexu byly následně použity pro ověřní existence demokratického deficitu muslimských, resp. arabských zemí na globální i regionální úrovni a také z hlediska vývoje v čase. Demokratický deficit je v kontextu této práce definován jako rozdíl mezi (průměrnými) hodnotami indexu srovnávaných skupin zemí.

Výsledky výzkumu ukázaly, že ačkoliv byl demokratický deficit formulován rozvojovou agenturou OSN téměř před dvaceti lety pro Arabský svět, stále je pro tuto část světa aktuální. Kromě toho bylo navíc zjištěno, že demokratický deficit je charakteristický také pro muslimský svět jako celek, nebot muslimské země vykázaly v průměru nižší hodnoty indexu než země nemuslimské. Komparace hodnot indexu dále ukázala, že arabské země v oblasti demokracie zaostávají dokonce i za ostatními (tj. nearabskými) muslimskými zeměmi. Výsledky navíc potvrdily, že za posledních přibližně 20 let nedošlo v podstatě k žádnému snížení demokratického deficitu muslimských ani arabských zemí.

Také v rámci jednotlivých světových regionů dosahují muslimské země horších výsledků než země nemuslimské. Největší takové rozdíly byly zaznamenány v regionu Blízkého východu, kde však srovnání není př́iliš relevantní, nebot se zde nachází pouze jedna nemuslimská země. Výrazný demokratický deficit muslimských zemí byl zaznamenán také v regionu Evropy a střední Asie, naopak muslimské země subsaharské Afriky měly deficit nejnižší.

Provedená studie navíc potvrdila, že ekonomický činitel je významný při zkoumání demokratického deficitu a jeho hloubky. Nejhorších výsledků v globálním srovnání dosáhly chudé, obvykle muslimské státy ze skupiny nejméně rozvinutých zemí, kterými jsou např́klad Jemen, Somálsko, Súdán nebo Eritrea. Občas se však i ekonomicky vyspělé státy ocitly mezi nejhůře hodnocenými zeměmi. Jedná se např́klad o Saúdskou Arábii a Bahrajn, které se v posledním analyzovaném období umístily mezi dvaceti nejhůře hodnocenými státy v indexu demokracie (v globálním srovnání). Nicméně také ostatní bohaté státy Perského zálivu (s výjimkou Kuvajtu) se umístily v nejhorší třetině klasifikovaných zemí. Z části se tak potvrdily závěry Rosse (2001) a Elbadawi, Makdisi, Milante (2011), kteří považují ropu a závislost na primárních zdrojích obecně jako škodlivou pro existenci demokracie $\mathrm{v}$ islámských zemích.

Výsledky analýzy mohou dále částečně naznačovat, že faktorem demokratického deficitu by mohl být také islám, jak o tom hovořily např́klad studie autorů Kendourie (1994), Hunting- 
ton (1996) či Fish (2002). Kromě dříve prezentovaných výsledků jsou totiž zjevná další zjištění. V prvním zkoumaném období se mezi deseti nejhưře hodnocenými zeměmi (podle indexu demokracie) nachází sedm muslimských zemí, ve druhém období šest a ve třetím období opět sedm. Mezi top deset zemí s nejvyšším hodnocením se neprobojovala žádná muslimská země ani v jednom ze tří období. Nejlepší muslimské země obsadily přičky kolem 110. místa (z celkových přibližně 170 zemí): v prvním a druhém období skončil nejlépe Senegal na 111., resp. 110. místě, a ve třetím období Tunisko na 119. místě. Výše uvedení autoři kromě islámu poukazovali také na arabskou kulturu, která má být podle nich neslučitelná s demokracií. Výsledky analýz opravdu mohou svádět k potvrzení této domněnky, nebot země Arabského světa se umístily v indexech rozvojových deficitů dokonce v průměru hưře než nearabské muslimské země.

Je však třeba dodat, že prezentované výsledky v žádném případě neříkají, že islám nebo arabská kultura jsou př́činou demokratického deficitu, nebo že jsou s demokracií neslučitelné. Výše uvedené analýzy indikují pouze souvislosti (byt ve většině př́ípadů relativně silné), v žádném případě však kauzální vztahy. $\mathrm{K}$ analýze takových otázek by bylo nutné aplikovat zcela jiný výzkumný rámec a metodologický přístup umožňující identifikovat faktory demokratického deficitu v islámských zemích. Aktuální výzkum může také sloužit jako vzor pro obdobné analýzy ostatních rozvojových deficitů arabských, resp. muslimských zemí, které byly identifikovány ve zprávách AHDR. Jedná se o deficit v oblasti znalostí a vzdělání, genderu či lidské bezpečnosti. Cúlem takových studií by byla kvantifikace deficitů za použití nově zkonstruovaných indexů (genderu, vzdělání, a bezpečnosti) a jejich následná analýza. Na tomto typu výzkumu již autoři předkládaného článku aktuálně pracují.

Na závěr lze shrnout, že i když hodnoty některých indikátorů v nejrůznějších oblastech demokratického indexu v mnoha arabských či muslimských zemích během posledních dekád vzrostly, většina těchto zemí nadále relativně zaostává v oblasti demokracie. Ačkoliv byl deficit poprvé pojmenován v roce 2002 organizací UNDP pro Arabský svět, tato studie ukázala, že je v průměru platný i dnes, a to nejen pro arabské státy, ale také pro muslimský svět na globální, ale i regionální úrovni.

\section{Bibliografie}

AHDR. 2002. „The Arab Human Development Report 2002. Creating Opportunities for Future Generations." [online] Arab Human Development Report [cit. 15. 10. 2020]. Dostupné z: https://arabhdr.org/report/opportunities-2002/, https://doi.org/10.2307/20033325.

AHDR. 2004. „The Arab Human Development Report 2004. Towards Freedom in the Arab World." [online] Arab Human Development Report [cit. 15. 10. 2020]. Dostupné z: https://arab-hdr.org/report/freedom2004/, https://doi.org/10.2307/20031755.

Barro, R. J. 1996. „Determinants of Economic Growth: A cross-country Empirical Study. “ Working paper No. 5698. Cambridge: National Bureau of Economic Research, https://doi.org/10.3386/w5698.

Beetham, D. 1998. „Democracy: Key principles, Institutions and Problems.“ Pp 21-31 in Ch. Bassiouni. Democracy: Its Principles and Achievement. Geneva: Inter-Parliamentary Union.

Benstead, L. J. 2014. „Why do some Arab citizens see democracy as unsuitable for their country?“ Democratization 22 (7): 1183-1208, https://doi.org/10.1080/13510347.2014.940041.

Bland, J. M., D. G. Altman. 1997. „Statistics notes: Cronbach's Alpha.“ BMJ (Clinical Research Ed.) 314: 572, https://doi.org/10.1136/bmj.314.7080.572.

Boldeanu, F. T., L. Constantinescu. 2015. „The main determinants affecting economic growth." Bulletin of the Transilvania University of Brasov 8 (2): 329-338.

Brooks, S. M., M. J. Kurtz. 2016. „Oil and Democracy: Endogenous Natural Resources and the Political ,Resource Curse." International Organization 70 (2): 279-311, https://doi.org/10.1017/ S0020818316000072.

Bureš, J. 2002. Conceptions of Constitutional Law in the Programmes of Islamist Movements. Mezinárodní vztahy 37 (3): 5-26. 
Cooper, W. W., P. Yue. 2008. Challenges of the Muslim World: Present, Future and Past. Bingley: Emerald Group Publishing Limited, https://doi.org/10.1016/s1571-0386(2008)19.

CSP. 2020. „Index.“ [online] Center for Systemic Peace [cit. 6. 12. 2020]. Dostupné z: https:// www.systemicpeace.org/index.html.

Dickey, Ch., E. Thomas. 2002. „How the US Helped Create Saddam Hussein. “ [online] Global Policy Forum, 23. 9. 2002 [cit. 20. 10. 2020]. Dostupné z: https://www.globalpolicy.org/component/content/article/ 167-attack/34978.html.

Dufek, P., J. Baroš, S. Bláhová, T. Křepelová, P. Taufar. 2019. Liberálni demokracie v době krize: Perspektiva politické filosofie. Praha: Slon.

Elbadawi, I., S. Makdisi. 2007. „Explaining the democracy deficit in the Arab World." The Quarterly Review of Economics and Finance 46 (5): 813-831, https://doi.org/10.1016/j.qref.2006.08.009.

Elbadawi, I., S. Makdisi, G. Milante. 2011. „Explaining the Arab democracy deficit. The role of oil and conflicts." Pp 41-83 in I. Elbadawi, S. Makdisi (eds.) Democracy in the Arab World: Explaining the deficit. New York: Routledge, https://doi.org/10.4324/9780203852866.

Fish, M. S. 2002. „Islam and Authoritarianism.“ World Politics 55 (1): 4-37, https://doi.org/10.1353/ wp.2003.0004.

Freedom House. 2018. „About Freedom in the World. An annual study of political rights and civil liberties." [online] Freedom House [cit. 22. 10. 2020]. Dostupné z: https://freedomhouse.org/report-types/ freedom-world.

Fukuyama, F. 2001. „The west has won.“ [online] The Guardian, 11. 10. 2001 [cit. 22. 10. 2020]. Dostupné z: https://www.theguardian.com/world/2001/oct/11/afghanistan.terrorism30.

Grim, B. J., T. M. Johnson, V. Skirbekk, G. A. Zurlo. 2015. Yearbook of International Religious Demography 2015. Leiden/Boston: Brill.

Haber, S. H, V. A. Menaldo. 2011. „Rainfall, Human Capital, and Democracy. “ [online] SSRN [cit. 20. 10. 2020]. Dostupné z: https://papers.ssrn.com/sol3/papers.cfm?abstract_id=1667332, https://doi.org/ 10.2139 /ssrn.1667332.

Hamid, S. 2011. „The Struggle for Middle East Democracy. “ [online] Brookings [cit. 15. 11. 2020]. Dostupné z: https://www.brookings.edu/articles/the-struggle-for-middle-east-democracy/.

Hassouna, H. A. 2001. „Arab Democracy: The Hope.“ World Policy Journal 18 (3): 49-52, https://doi.org/ 10.1215/07402775-2001-4007.

Hellyer, H. A. 2018. „The Islamic Tradition and the Human Rights Discourse.“ [online] Atlantic Council / Rafik Hariri Center for Middle East [cit. 13. 10. 2020]. Dostupné z: https://www.atlanticcouncil.org/indepth-research-reports/report/the-islamic-tradition-and-the-human-rights-discourse/.

Huntington, S. 2001. Střet civilizací: Boj kultur a proměna světového rádu. Praha: Rybka Publishers.

Chaney, E. 2012. „Democratic Change in the Arab World, Past and Present." Brookings Papers on Economic Activity 2012 (1): 363-414, https://doi.org/10.1353/eca.2012.0002.

Kahf, M. 1997. „Instruments of Meeting Budget Deficit in Islamic Economy. “ [online] The Islamic Research and Teaching Institute (IRTI) [cit. 2. 11. 2020]. Dostupné z: http://monzer.kahf.com/papers/english/ INSTRUMENTS_FOR_MEETING_budget_deficit.pdf.

Karatnycky, A. 2002. „Muslim Countries and the Democracy Gap.“ Journal of Democracy 13 (1): 99-112, https://doi.org/10.1353/jod.2002.0009.

Kedourie, E. 1994. Democracy and Arab Political Culture. $2^{\text {nd }}$ edition. London: Routledge, https://doi.org/ $10.4324 / 9781315037257$.

Kirkpatrick, J. J. 1984. „Democratic Elections and Democratic Government.“ World Affairs 147 (2): 61-69.

Kropáček, L. 2011. Duchovní cesty islámu. Praha: Vyšehrad.

Křikavová, A., M. Mendel, Z. Müller, V. Dudák. 2002. Islám - ideál a skutečnost. Praha: Baset.

Lipset, S. M. 1994. „The Social Requisities of Democracy Revisited." American Sociological Review 59 (1), 1-22, https://doi.org/10.2307/2096130.

Liu, Z. 2015. „Middle East Upheavals and Democratic Transition of Arab Countries. “ Journal of Middle Eastern and Islamic Studies (in Asia) 9 (2): 38-72, https://doi.org/10.1080/19370679.2015.12023262.

Manly, F. J. 2004. Multivariate Statistical Methods: A Primer. New York: CRC Press, https://doi.org/ $10.1201 / \mathrm{b} 16974$.

Miller, L. E., J. Martini. 2013. Democratization in the Arab World: A Summary of Lessons from Around the Globe. Santa Monica: RAND Corporation. 
OIC. 2020. „Member States." [online] Organisation of Islamic Cooperation [cit. 6. 12. 2020]. Dostupné z: https://www.oic-oci.org/states/?lan=en.

Orihuela, J. 2018. „Institutions and place: Bringing context back into the study of the resource curse." Journal of Institutional Economics 14 (1): 157-180, https://doi.org/10.1017/S1744137417000236.

Pew Research Center. 2009. „The Global Middle Class.“ [online] Pew Research Center [cit. 10. 10. 2020]. Dostupné z: https://www.pewresearch.org/global/2009/02/12/the-global-middle-class/.

Puddington, A. 2014. „Freedom in the World 2014. The Annual Survey of Political Rights \& Civil Liberties." [online] Freedom House [cit. 2. 11. 2020]. Dostupné z: https://freedomhouse.org/sites/default/ files/2020-02/Freedom_in_the_World_2014_complete_book.pdf.

Puddington, A. 2015. „Freedom in the World 2015. The Annual Survey of Political Rights \& Civil Liberties." [online] Freedom House [cit. 3. 11. 2020]. Dostupné z: https://freedomhouse.org/sites/default/ files/2020-02/Freedom_in_the_World_2015_complete_book.pdf.

Puddington, A. 2017. „Freedom in the World 2017. The Annual Survey of Political Rights \& Civil Liberties." [online] Freedom House [cit. 3. 11. 2020]. Dostupné z: https://freedomhouse.org/sites/default/ files/2020-02/Freedom_in_the_World_2017_complete_book.pdf.

Puddington, A. 2018. „Freedom in the World 2018. The Annual Survey of Political Rights \& Civil Liberties." [online] Freedom House [cit. 3. 11. 2020]. Dostupné z: https://freedomhouse.org/sites/default/ files/2020-02/FreedomintheWorld2018COMPLETEBOOK.pdf.

Riaz, A. 2016. „Challenges to Islamic Education." South Asian Journal of Social Sciences 1 (2): 1-23.

Ross, M. L. 2001. „Does oil hinder democracy?“ World Politics 53 (3): 325-361, https://doi.org/10.1353/ wp.2001.0011.

Ross, M. L. 2012. The Oil Curse: How petroleum weath shapes the development of nations. Princeton, NJ: Princeton University Press.

Sarkissian, A. 2012. „Religious regulation and the Muslim Democracy Gap.“ Politics and Religion 5 (3): 501-527, https://doi.org/10.1017/s1755048312000284.

Shahin, E. 2015. „Government.“ Pp 68-85 in G. Bowering (ed.) Islamic Political Thought: An Introduction. Woodstock: Princeton University Press, https://doi.org/10.23943/princeton/9780691164823.003.0005.

Sharkansky, I. 1995, „R. L. Rothstein (Ed.): Democracy, Peace, and the Israeli-Palestinian Conflict [book review]." Shofar: An Interdisciplinary Journal of Jewish Studies 13 (4): 124-126, https://doi.org/ 10.1353/sho.1995.0097.

Sottilotta, C. E. 2013. „Political Stability in Authoritarian Regimes: Lessons from the Arab Uprisings." IAI Working papers 13 (01). Roma: The Istituto Affari Internazionali.

Stepan, A. C., G. B. Robertson. 2003. „An „Arab' More Than a ,Muslim Democracy Gap. “ Journal of Democracy 14 (3): 30-44, https://doi.org/10.1353/jod.2003.0064.

The Economist. 2020. „Democracy Index 2019.“ [online] The Economist [cit. 6. 12. 2020]. Dostupné z: https://www.eiu.com/topic/democracy-index.

Transparency International. 2020. „Corruption Perception Index.“ [online] Transparency International [cit. 6. 12. 2020]. Dostupné z: https://www.transparency.org/en/cpi\#.

WB. 2019. „Indicators." [online] The World Bank [cit. 16. 9. 2020]. Dostupné z: https:// data.worldbank.org/indicator.

\section{O autorech}

Pavla Vítová je studentkou doktorského studijního programu Mezinárodní rozvojová studia na Univerzitě Palackého v Olomouci. Ve svém výzkumu se zabývá rozvojovými deficity v zemích Blízkého východu a ostatních muslimských státech. Na Rektorátu Univerzity Palackého v Olomouci se současně podílí na zajištování studijních programů univerzity v iráckém Erbílu. ORCID: https://orcid.org/0000-0001-78284144.

Jaromír Harmáček je odborným asistentem na Katedře rozvojových a environmentálních studií Př́rodovědecké fakulty Univerzity Palackého v Olomouci. Zabývá se rozvojovou ekonomií a využitím kvantitativních metod v rámci rozvojových i environmentálních studií. ORCID: https://orcid.org/0000-0002-37110663. 


\section{Summary}

United Nations Development Programme (UNDP) identified in 2002 three fundamental areas of human development in which the Arab world lags behind the rest of the world. One of those specified areas was the lack of freedom and democracy. This paper aims to define and describe the democratic deficit in the context of the Muslim world, verify its existence in the Arab world, and determine its possible presence in Muslim countries across various world regions. To investigate the presence of the democratic deficit, the study introduces a composite democracy index that measures and compares countries' performances in democratic domains.

The introductory part of the paper describes and defines democracy and explains the main characteristics of a democratic form of government. These consist of regular elections, pluralistic systems, constitutional governments, and majority rule (while protecting minorities). The second section presents the literature review of studies focused on the democratic deficit and pitfalls of democracy in the Muslim and Arab worlds. While several authors present the civil war and the Arab-Israeli conflict as one of the barriers to democracy, others emphasize the dependence on primary resources (such as oil) or the patriarchal and clan societies.

The third section then examines the broader theoretical context as well as the deeper causes of the democratic deficit in the Muslim world. It explains the relationship between religion (Islam), state, and democracy. In Islam, the difference between religion and state is nonexistent because both components are part of Islam, and therefore the interests of both should be identical. However, in political practice, state policy is often separated from religion, and thus, Islam is not the main factor in the state's domestic and foreign policy. Then, the possible causes of the deficit are presented, as well as the examples of the manifestation of the democratic deficit around the Muslim world, such as non-democratic elections, persecution of minorities, bloggers or journalists.

The following fourth section of the paper presents the research methodology, clarifies the concept of a Muslim country, and introduces the construction and calculation of the composite index. The democracy index consists of three components: personal rights, personal liberties, equal treatment, and absence of discrimination. Each component includes four democracy indicators covering three time periods 19982000, 2008-2010, and 2016-2018. Each component's scores for individual countries are calculated using a weighted average of the four indicators within each component, where weights are decided statistically by a method called principal component-factor. The scores for the democracy index for individual countries are calculated as a simple average of the three components' scores. The scores are used to test the presence of the democratic deficit for the group of Muslim countries (including the Arab countries; against nonMuslim countries) and the group of Arab countries (against the rest of Muslim countries). To test this, regression analyses with dummy variables are performed while controlling for GNI per capita.

Section five presents the results, which are then discussed and summarized in the paper's final section. The results showed that although the deficit was formulated almost twenty years ago, it is still relevant. It has been observed that Muslim countries performed, on average, worse on the democratic index than non-Muslim countries, which means that the Islamic countries have to deal with the democratic deficit as well. Moreover, the results also showed that the performance of the Arab world in the democratic index is even worse than that of the other Muslim countries. The analysis also confirmed that the economic factor is important in verification of the deficit and its depth. On the level of individual countries, poor Muslim states often achieved the worst results, usually from the group of the least developed countries, such as Yemen, Somalia, Sudan, or Eritrea. 


\section{Přiloha 1: Přistup AHDR k demokratickému deficitu a navržené indikátory pro index de- mokracie}

Komponenty indexu jsou navrženy v souladu s AHDR (2004), která demokratický deficit arabských zemích vnímá zejména z perspektivy osobních práv a svobod. V úvodu report také zmiňuje, že lidé mají právo na důstojný hmotný, morální a duchovní život, který není slučitelný s jakoukoliv formou diskriminace. Proto je index demokracie, který je následně využíván k měření demokratického deficitu muslimských, resp. arabských zemí, složen z uvedených tří komponent (osobní práva, osobní svobody, a rovné zacházení a absence diskriminace). Tento přístup je inspirován také metodikou a složením Indexu společenského pokroku, Social Progress Index (Stern et al. 2020), který v jedné ze svých dimenzí aproximuje přístup k demokracii osobními právy a osobními svobodami. Indikátory do jednotlivých komponent indexu proto byly voleny tak, aby odpovídaly přístupu zejména AHDR (2004) a částečně se opíraly také o Index společenského pokroku. Kromě indikátorů, které jsou použity v této práci ve finální verzi indexu demokracie (viz Příloha 2), byly zvažovány také další proměnné. Ty však nakonec nemohly být použity zejména z důvodu nedostupnosti dat nebo nedostatečné konceptuální či statistické koherence. Jedná se zejména o následující indikátory (v závorce je uvedený zdroj): Index rovné ochrany (V-Dem), Podíl populace s volebním právem (V-Dem), Polity IV Index (CSP), Index demokracie (The Economist), Index vnímání korupce (Transparency International).

\section{Prĭloha 2: Zkratky proměnných, které byly využity pro konstrukci indexu demokracie}

\begin{tabular}{|c|c|c|c|}
\hline Zkratky proměnných & Název proměnných (ČJ) & Název proměnných (AJ) & Zdroj \\
\hline $\operatorname{dem} 1$ & Osobní práva & Personal rights & \\
\hline proprights & Vlastnická práva & Property rights & V-Dem \\
\hline accjust & Přístup ke spravedlnosti & Access to justice & V-Dem \\
\hline polrightagg & Politická práva & Political rights & Freedom House \\
\hline rulelaw & Úroveň právního státu & Rule of law & $\begin{array}{l}\text { Worldwide Government } \\
\text { Indicators }\end{array}$ \\
\hline $\operatorname{dem} 2$ & Osobní svobody & Personal freedoms & \\
\hline corruption & Vnímání korupce & Control of corruption & $\begin{array}{l}\text { Worldwide Government } \\
\text { Indicators }\end{array}$ \\
\hline freedrelig & Svoboda vyznání & Freedom of religion & V-Dem \\
\hline freexp & Svoboda vyjadřování & Freedom of expression & V-Dem \\
\hline persautonomy & $\begin{array}{l}\text { Osobní autonomie } \\
\text { a individuální práva }\end{array}$ & $\begin{array}{l}\text { Personal autonomy } \mathcal{E} \\
\text { Individual rights }\end{array}$ & $\begin{array}{l}\text { Freedom House; Civil } \\
\text { liberties - indikátor G }\end{array}$ \\
\hline dem3 & $\begin{array}{l}\text { Rovné zacházení } \\
\text { a absence diskriminace }\end{array}$ & $\begin{array}{l}\text { Equal treatment and } \\
\text { absence of discrimination }\end{array}$ & \\
\hline minordiscr & $\begin{array}{l}\text { Diskriminace a násilí vůči } \\
\text { menšinám }\end{array}$ & $\begin{array}{l}\text { Discrimination and violence } \\
\text { against minorities }\end{array}$ & Fund for Peace, FSI \\
\hline eqdistres & $\begin{array}{l}\text { Index rovnoměrného } \\
\text { rozdělení zdrojů }\end{array}$ & $\begin{array}{l}\text { Equal distribution of } \\
\text { resources index }\end{array}$ & V-Dem \\
\hline eqpowersocgrp & $\begin{array}{l}\text { Rovnost politické moci } \\
\text { sociálních skupin }\end{array}$ & $\begin{array}{l}\text { Equality of political power } \\
\text { by social group }\end{array}$ & V-Dem \\
\hline eqpowersocpos & $\begin{array}{l}\text { Rovnost politické moci podle } \\
\text { socioekonomického postavení }\end{array}$ & $\begin{array}{l}\text { Equality of political power } \\
\text { by socioeconomic position }\end{array}$ & V-Dem \\
\hline
\end{tabular}


Přilloha 3: Korelační tabulky

\begin{tabular}{|c|c|c|c|c|c|c|c|c|c|c|c|c|}
\hline & 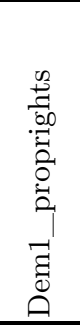 & 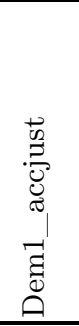 & 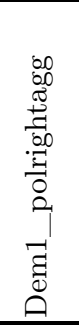 & 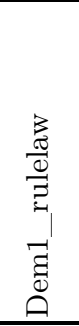 & 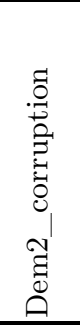 & 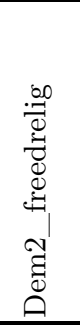 & 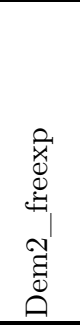 & 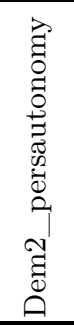 & 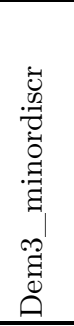 & 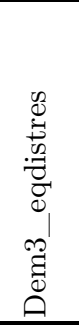 & 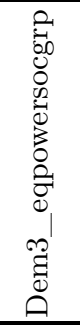 & 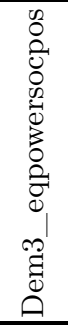 \\
\hline Dem1_proprights & 1,00 & & & & & & & & & & & \\
\hline Dem1_accjust & 0,73 & 1,00 & & & & & & & & & & \\
\hline Dem1_polrightagg & 0,75 & 0,78 & 1,00 & & & & & & & & & \\
\hline Dem1_rulelaw & 0,62 & 0,78 & 0,70 & 1,00 & & & & & & & & \\
\hline Dem2_corruption & & & & & 1,00 & & & & & & & \\
\hline Dem2_freedrelig & & & & & 0,39 & 1,00 & & & & & & \\
\hline Dem2_freexp & & & & & 0,52 & 0,72 & 1,00 & & & & & \\
\hline Dem2_persautonomy & & & & & 0,76 & 0,65 & 0,76 & 1,00 & & & & \\
\hline Dem3_minordiscr & & & & & & & & & 1,00 & & & \\
\hline Dem3_eqdistres & & & & & & & & & 0,57 & 1,00 & & \\
\hline Dem3_eqpowersocgrp & & & & & & & & & 0,49 & 0,49 & 1,00 & \\
\hline Dem3_eqpowersocpos & & & & & & & & & 0,46 & 0,53 & 0,62 & 1,00 \\
\hline
\end{tabular}

Zdroj: vlastní zpracování.

Pozn.: Uvedeny jsou korelační koeficienty finálně upravených proměnných (tedy standardizovaných na z-scores, popř. transformovaných a invertovaných).

Přiloha 4: Výsledky faktorové analýzy (Principal component factor, PCF)

\begin{tabular}{lllll}
\hline & & Dem1 & Dem2 & Dem3 \\
\hline Počet pozorování & & 526 & 522 & 511 \\
\hline Počet parametrů & & 4 & 4 & 4 \\
\hline \multirow{2}{*}{ Eigen values } & Faktor 1 & 3,19 & 2,93 & 2,59 \\
& Faktor 2 & 0,39 & 0,67 & 0,62 \\
& Faktor 3 & 0,23 & 0,26 & 0,44 \\
\hline Počet faktorů v analýze & 0,19 & 0,14 & 0,35 \\
\hline
\end{tabular}

Zdroj: vlastní zpracování.

Pozn.: Každá ze tří komponent indexu (Dem1-Dem3) má právě jeden základní faktor, což ukazuje eigenvalue větší než jedna pouze pro první (a žádný další) faktor. 
Přiloha 5: Hodnoty Cronbachovy alfy a KMO pro komponenty indexu demokracie

\begin{tabular}{lll}
\hline Komponenty indexů & Cronbachova alfa & KMO \\
\hline Osobní práva & 0,92 & 0,83 \\
Osobní svobody & 0,88 & 0,72 \\
Rovné zacházení a absence diskriminace & 0,82 & 0,77 \\
\hline
\end{tabular}

Zdroj: vlastní zpracování.

Pozn.: Pro validitu výsledků je žádoucí, aby hodnota alfy byla větší než 0,7 a hodnota KMO větší než 0,5 .

Oba požadavky jsou splněny pro všechny tři komponenty demokratického indexu.

\section{Přiloha 6: Vývoj demokratického deficitu v arabských zemích}

\begin{tabular}{|c|c|c|c|c|c|c|}
\hline \multicolumn{7}{|c|}{ Závislá proměnná: index demokracie } \\
\hline & $\begin{array}{c}\text { model } 1 \\
(1998-2000)\end{array}$ & $\begin{array}{c}\text { model } 2 \\
(2008-2010)\end{array}$ & $\begin{array}{c}\text { model 3 } \\
(2016-2018)\end{array}$ & $\begin{array}{c}\text { model } 4 \\
(1998-2000)\end{array}$ & $\begin{array}{c}\text { model } 5 \\
(2008-2010)\end{array}$ & $\begin{array}{c}\text { model } 6 \\
(2016-2018)\end{array}$ \\
\hline \multirow{2}{*}{ Arabské země } & $-5,56$ & $-4,79$ & $-4,61$ & $-9,93^{*}$ & $-7,11$ & $-3,18$ \\
\hline & $(4,27)$ & $(4,35)$ & $(5,03)$ & $(4,94)$ & $(5,12)$ & $(6,07)$ \\
\hline \multirow{2}{*}{ ln_HND } & & & & $3,51^{* *}$ & 2,69 & 1,14 \\
\hline & & & & $(1,58)$ & $(1,73)$ & $(2,20)$ \\
\hline Koef. determinace $\mathrm{R}^{2}$ & 0,04 & 0,03 & 0,02 & 0,10 & 0,063 & 0,010 \\
\hline Počet pozorování & 45 & 45 & 45 & 43 & 43 & 43 \\
\hline
\end{tabular}

Zdroj: vlastní zpracování.

Pozn.: uvedeny jsou regresní koeficienty, v závorce jsou směrodatné chyby robustní vůči heteroskedasticitě. Regresní koeficienty jsou významné na: *** $1 \%$ hladině, ${ }^{* *} 5 \%$ hladině, ${ }^{*} 10 \%$ hladině. Koeficient determinace $\mathrm{R}^{2}$ nabývá hodnot od nuly do jedné a udává, jak velká část variability závislé proměnné (tedy skóre demokratického indexu) byla modelem vysvětlena. 